\title{
Why Using Religious Arguments in the Euthanasia Discussion is Problematic*
}

\author{
Theodoor A. Boer ${ }^{\mathrm{a}}$
}

\begin{abstract}
In discussions about assisted dying (euthanasia, assisted suicide), those who argue 'against' legalisation often reason from a religious angle, whereas those 'in favour' adopt a secular stance. The Dutch experience is more nuanced: here, euthanasia advocacy largely originated from protestant religious believers. In this contribution, I criticise the use of religious arguments favouring any specific position. Religion may provide a heuristic context to explore norms relevant in the discussion, and religion may help us formulate our personal stance. But when it comes to societal debates (often focusing on whether or not to legalise euthanasia), we should concentrate on legal, societal, empirical, and ethical arguments that are understandable to all.
\end{abstract}

Keywords: Euthanasia; assisted dying; assisted suicide; religion; the Netherlands

Received: 25/11/2020 Accepted: 24/02/2021

Available online: $23 / 07 / 2021$

How to cite: Boer TA. Why Using Religious Arguments in the Euthanasia Discussion is Problematic. Rev. latinoam. bioet [Internet]. 2021Jul.23 [cited 2021Jul.23];21(1):127-136. Available from: https:// revistas.unimilitar.edu.co/index.php/rlbi/article/view/5450

* Research article

a PhD, Protestant Theological University, Groningen, The Netherlands.

E-mail: taboer@pthu.nl

ORCID: http://orcid.org/0000-0002-0026-7974 


\section{Por qué hacer uso de argumentos religiosos en el debate sobre la eutanasia es un tema problemático}

Resumen: en discusiones sobre la muerte asistida (eutanasia, suicidio asistido), aquellos que argumentan estar "en contra" de la legalización a menudo razonan desde un ángulo religioso, mientras que los que están "a favor" adoptan una postura secular. La experiencia holandesa es más matizada: aquí, la defensa de la eutanasia se originó en gran medida por creyentes religiosos protestantes. En esta contribución, critico el uso de argumentos religiosos que favorezcan cualquier posición específica. La religión puede proveer un contexto heurístico para explorar normas relevantes en la discusión, y la religión puede ayudarnos a formular nuestra postura personal. Pero cuando se trata de debates sociales (a menudo enfocados en la legalización o no de la eutanasia), debemos concentrarnos en argumentos jurídicos, sociales, empíricos y éticos que sean comprensibles para todos.

Palabras clave: eutanasia; muerte asistida; suicidio asistido; religión; Países Bajos

\section{Por que usar argumentos religiosos no debate sobre a eutanásia é um tema problemático}

Resumo: Em discussões sobre a morte assistida (eutanásia, suicídio assistido), os que argumentam estar "contra" a legalização com frequência pensam a partir de um ângulo religioso, enquanto os que estão "a favor" adotam um posicionamento secular. A experiência holandesa é mais fusionada: aqui, a defesa da eutanásia foi originada em grande medida por crentes religiosos protestantes. Nesta contribuição, critico o uso de argumentos religiosos que favoreçam qualquer posicionamento específico. A religião pode promover um contexto heurístico para explorar normas relevantes na discussão, e a religião pode ajudar-nos a formular nosso posicionamento pessoal. Contudo, quando é tratado de debates sociais (às vezes focados na legalização ou não da eutanásia), devemos concentrar-nos em argumentos jurídicos, sociais, empíricos e éticos que sejam compreensíveis para todos.

Palavras-chave: eutanásia; morte assistida; suicídio assistido; religião; Países Baixos 


\section{Introduction}

In many discussions, religious people are either known as or assumed to be more reserved towards assisted dying than secular people. In most countries where assisted dying is legal or where legalisation is under consideration, the strongest opposition is heard from religious people: observant Roman-Catholics and conservative Protestants. Strong opposition is also found among physicians and their organisations. Voices from non-religious persons who are not doctors are rare, but exist, such as the Canadian-British atheist and historian Kevin Yuill (1). Secular examples are also found in the Netherlands, but they seem to be directed against certain applications of euthanasia only-most notably, euthanasia in patients with dementia or a psychiatric condition-, not against euthanasia itself (2).

In this contribution, I seek to shed light on the relations between euthanasia and religion. I will do this from a Dutch context, not only because the Netherlands has the longest tradition worldwide in debating and regulating voluntary euthanasia, but also because many Dutch euthanasia advocates have religious backgrounds, motivations, and arguments. Post-war Dutch thinking about euthanasia was initiated by the Leiden psychiatrist Jan Hendrik Vandenberg, who in 1969 published an influential pamphlet entitled Medical Power and Medical Ethics (3). Vandenberg argued that advances in medical technology, which have led to more and better treatment options, also cause much suffering. Doctors should not only practice reticence in treating patients with a poor prognosis, but also have the courage to end a patient's life actively.

The 1970s and 1980s saw the ground-breaking court cases that led to an agreement in 1985 between the Ministry of Health, the Public Prosecutor, and the Royal Dutch Medical Association that euthanasia would not be punished if several criteria were fulfilled: a competent patient's request, unbearable suffering without prospect of improvement, and the absence of alternatives to alleviate the suffering. The year 1994 saw the first euthanasia law, 'hidden' as a particular clause to the Burial and Cremation Act, and in 2002 a second law was introduced that has remained unchanged ever since (4). Euthanasia and medical assistance in suicide remain part of the Criminal Code, but if conducted following the due care criteria and reported to one of the five Regional Review Committees, a physician can be confident that there will be no prosecution. Dutch law does not regard euthanasia as a standard medical procedure. There is no patient right to it, nor is there a duty on individual or institutional caregivers to provide euthanasia.

In the first years after the 2002 legalisation, the reported numbers remained at about 2,000 annually and took place almost entirely in mentally competent and terminally ill patients. There was initial relief that "this is about the level of euthanasia the Netherlands will see" (5). Not much later, three significant changes occurred: the reported numbers went up from around 1,900 in 2002 to 6,938 in 2020 , and they are expected to continue increasing; the underlying pathology for a euthanasia request expanded from terminal to chronic and psychiatric diseases, and the public increasingly see euthanasia as a default death (6).

Although euthanasia nationally accounts for $4.5 \%$ of all deaths, this rate is up to $14 \%$ in certain urban and secularised districts (7). Luckily, the quality of palliative care in the Netherlands, as in most other western democracies, significantly improved and is deemed by some to be second in Europe and fifth worldwide in terms of quality (8). While the medical necessity for active killing has diminished over the years, its incidence increased. Thus, we can conclude that euthanasia has undergone a metamorphosis: from an ultimate remedy to prevent physical discomfort to a remedy to address a patient's loneliness, sense of dependence, and lack of self-determination. From the last resort to prevent a dreadful and-for the relativestraumatising deathbed, it has increasingly become a means to prevent a terrible life.

\section{Theological Arguments about Assisted Dying}

Let us concentrate now on the theology of euthanasia. Needless to say, there are recurring religious arguments against intentionally and directly 
killing yourself or having yourself killed. First and foremost, killing is one of the offences listed in the Ten Commandments, the primary moral charter of Judaism and Christianity. The question, of course, is whether this, i.e., the sixth commandment, also applies to a self-chosen death; although nowhere in the Bible suicide is justified or recommended, an outright rejection of suicide is also absent. The self-chosen end seems to fall in the category of tragedy rather than sin. Still, it is important to note that the sixth commandment throughout church history has been interpreted to include suicide. Secondly, there is the view that God is the creator of life and that humans have no right to undo this creation: rather than proprietors of life, humans are its stewards. Thirdly, with particular reference to the hardships of illnesses, there is the argument that living through a disease will foster one's virtues, such as patience and love, so that a patient may be more fit to enter heaven at the end of their lives. Last but not least, there is the argument that God is powerful and loving enough to support and comfort those who are in pain and despair.

However, there are also arguments in favour. It may not be entirely coincidental that euthanasia and other forms of assisted dying are only legal in countries with a Christian past. The Netherlands, Switzerland, the US (where assisted suicide is now possible in ten states), Australia, and New Zealand have mixed Protestant and Roman Catholic roots; Colombia, Belgium, and Luxembourg have Roman-Catholic origins predominantly. Since these countries have experienced decades of secularisation, the question is: Is the acceptance of assisted dying in some way a consequence of this religious past or must it be explained as a strong secular reaction to this past?

Most probably, it depends on the country and its history. In Belgium, the legalisation of euthanasia and the acceptance of one of the most liberal euthanasia regimes globally is arguably a strong reaction of a secularised political elite to times in which the Roman Catholic church and the Christian Democratic party dominated the country. The country's process of legalisation went remarkably swift as it took only some years. However, for the Netherlands, through the geographic and linguistic proximity to Belgium - in all likelihood a leading example-, the picture is different. The advocacy of euthanasia in the Netherlands is rooted in liberal Protestantism. The aforementioned psychiatrist Vandenberg was a liberal protestant and published his book Medical Power and Medical Ethics with an orthodox Christian publisher.

Three years later, in 1972, the Dutch Reformed Church, little short of the nation's state church at the time, issued a synodical report in which euthanasia was recommended (9). It was built on several premises: the awareness that much suffering is caused by physicians (an idea taken from Vandenberg), the increasing number of older people, and the consequentialist conviction that active euthanasia differs only marginally from decisions to refrain from potential life-saving treatment. In complete ignorance of the significance of the sixth commandment, the report's focus is on quality of life, the capacity to communicate as a basic human characteristic, the need for a just distribution of scarce resources, and the liberty humans have to decide although their lives are a gift from God. Twelve years later, another protestant church, the Reformed Churches in the Netherlands, issued a similar report (10). The report concluded that in situations of humiliating suffering, "requests for euthanasia should-even in the Church of Christ-not be declined or disapproved beforehand." The report also suggested that physically ill patients and psychiatric patients should have access to euthanasia.

It must be said that these Reformed reports did not suggest that euthanasia should be legal. In a later report, issued in 1999 and criticised by liberal pastors for being 'a jolt to the right,' both churches rejected legalisation (11). Nevertheless, it should not be underestimated that the churches had broken the taboo and had advocated euthanasia as an emergency solution, which may explain why euthanasia in the Netherlands has never been formally legalised: despite the high numbers and despite a certain normalcy, euthanasia remains part 
of the criminal code and can officially be excused after a euthanasia review committee has approved a euthanasia procedure already performed. A license to provide euthanasia beforehand is not given; euthanasia is neither a patient's right, let alone a physician's or an institution's obligation.

In the past fifty years, the Roman Catholic church and some smaller protestant denominations remained consistently dismissive, but their influence was limited politically and culturally. Of more importance was the influence of mainstream Reformed theologians, ethicists, and physicians. One of the first theologians to condone euthanasia was the popular Dutch Reformed pastor and author J.J. Buskes (12). Whereas in 1964 Buskes had argued that euthanasia means "crossing a line that we are not allowed to cross," he later welcomed Vandenberg's courage to put active euthanasia on the agenda: "in the years in which I was a hospital chaplain I [...] witnessed the cruelty of the medical power applied almost convulsively to the utmost" (13). In 1972 the Groningen theological ethicist Pieter Roscam Abbing authored a study with a theme similar to Vandenberg: Increased Responsibility (14). Just like his church did in that same year, Roscam Abbing suggested that elderly citizens practice 'responsible senior citizenship' and make a place for new generations. Although he was hesitant about nonvoluntary euthanasia, he suggested that this option should not be ruled out in the future.

Much of this early thinking was of a predominantly paternalistic character, suggesting that euthanasia may be the best solution for both the individual and the community. The foundation of the Right to Die Society NVve in 1972, with the term 'voluntary' prominent in its name, was a morally and strategically necessary correction. In 1978, Roscam Abbing's colleague in Utrecht, professor of theological ethics Hannes de Graaf, co-authored an NVVE-report that advocated voluntary euthanasia (15). Also, the charismatic Protestant ethicist and NVVE-chairperson 1981-1985 Heleen Dupuis emphasised the need for voluntariness. As a result, the definition of euthanasia evolved into a more autonomous concept (16). Without a patient request, active killing is not even 'euthanasia.'
A thinker whose importance can hardly be underestimated is the Reformed theologian and member of the Dutch Health Council, Harry Kuitert. In three subsequent publications, this most well-read public theologian of his days deconstructed some of the core Christian arguments against euthanasia (17-19). Reverence for life, for example, does not mean that humans may not decide to kill but instead that they may not do so randomly. Nor is the traditional Christian reverence for a natural death a conclusive argument against euthanasia: from the fact that death is natural does not follow that only a natural death is allowed. As anthropologist Anne-Mei The describes, "The fact that Kuitert was of Reformed origin played an important role in accepting euthanasia. He heavily influenced his religious audience and dampened part of the conservative reserves against euthanasia" (20). According to historian James Kennedy, the Reformed theologians Kuitert and Dupuis, together with two others, formed the very 'euthanasia-elite' in the formative 1980s (21). Although the Reformed churches had theological faculties at six universities, other mainstream reformed ethicists offered no serious opposition. I think this phenomenon of religious advocacy of euthanasia is not exclusively Dutchwe find Christian 'pro' voices in almost any debate-but due to its intensity and influence, we can safely say that it is specifically Dutch (22).

\section{Why Using Theological Arguments in the Context of Assisted Dying is Problematic}

In this section, I want to problematise the use of theological arguments in any assisted dying debate, whether for or against legalisation. Certainly, the topic of a self-chosen and self-orchestrated death raises religious questions, no wonder, and people who feel the urge to bring these arguments to the fore are welcome to do so. However, after having been part of topical discussions for 35 years, I have become increasingly sceptical about using such arguments in the public debate about assisted dying.

Why? First, although assisted dying debates are often strongly ethical in tone, the question at 
the end of the day is: Should assisted dying be legal? Often, a legal discourse focuses on only two aspects: securing maximum liberty for all and protecting the rights of vulnerable people. In that minimal scope, it is difficult to find how religious arguments would weigh in. Let us take arguments against euthanasia: the belief that God has forbidden intentional killing, the belief that God will comfort and strengthen those who are at the end of their lives, the belief that illnesses may make us stronger, the belief that how and when we die is for God to decide, etcetera-they may all be highly relevant for some to reject euthanasia personally.

Similarly, those who advocate euthanasia may be religiously inspired, e.g., through the conviction that God grants us the liberty to take our own lives, for example, the belief that God does not intend unbearable suffering, or the conviction that the hope for an afterlife may erase our fear of death. For many believers, especially those who spell god with a capital ' $G$ ' (i.e., those who ascribe the traditional qualities of wisdom, goodness, and power to God), such religious arguments may be among the most decisive for their moral stance. Through the detour of elections and referenda, religious arguments may play a vital role procedurally. Nevertheless, they should not be relevant in the legislative process merely because they are religious or deeply held. After all, those holding these restricted views are not forced to revise them, nor are they forced to make use of the option of euthanasia once it is legal. (It becomes more complex, however, in countries such as Canada and Belgium, where physicians or institutions may have a duty to provide euthanasia.) Deeply held Christian convictions about the givenness of life do not justify a ban on assisted dying, any more than the Christian conviction that Christ is the Lord justifies a ban on being a practising Muslim or a secularist.

A second reason to be hesitant in using religious arguments in the legislative process applies to religious arguments in favour and can be subsumed as follows: Why would a religion provide us with arguments to be more liberal than a liberal democracy allows, why would it license us to be less protective of life than non-religious people, and why would it allow us to give up more lightly in the face of unbearable suffering than those who do not share the Christian hope? Let us look at two such arguments: the belief in an afterlife and the belief that life is God's gift entirely at our disposal. For the American ethicist Daniel Maguire, belief in an afterlife is an essential argument favouring euthanasia.

For a Christian and for anyone who believes in an afterlife, to 'terminate life' is not to terminate life, but to move on to a new life .. . This would seem to make it easier for a Christian to see death as a friend, especially when he or she has, through illness, lost all ability to respond and react to the invitation of his God to join him in the building up of this earth (23).

Many religious people describe life in terms of a divine gift (24). The American philosopher Margaret Papst Battin uses this metaphor in favour of a right to choose death. "[I]f life is really a gift from God to the individual, it is that. . person's right to do with it as he or she chooses" (25). The French Roman Catholic clergyman Jacques Pohier expresses himself even more sharply:

God does not give people only partial freedom to reserve for themselves a 'domain of their own.' It is almost blasphemous to think that God gave us life without our having access to it, for better or for worse, according to our own judgment (26).

I do not discard beforehand attempts to legalise assisted dying, just like we should not discard attempts not to legalise it. However, let us be clear about this: in all conceivable respects, the direct and intentional killing of a human being, even when it happens at their request, is an act with a tremendous impact—ethically, medically, societally, legally, and religiously. Euthanasia is highly consequential, irreversible, unrepeatable, exceptional. It affects the lives and emotions of family members and caregivers. It is 'unnatural' and runs counter to what most societies see as their core business: protecting life and making life happier. Again, one may plausibly advocate a more liberal practice-although I would suggest that no legalisation should go beyond euthanasia as a last resort-, just like 
plausible arguments for the limited use of deadly force in armed conflicts have been made.

Nevertheless, assisted dying remains killing. Just like in war, one should be cautious about allowing religious arguments to justify licenses to kill. I can witness from the euthanasia reports I reviewed on behalf of the Dutch government that expectations about a happy heavenly life constitute one of the motivations behind a considerable number of euthanasia requests. Patients expect to be reunited with their loved ones, deceased parents, stillborn children. Many expect a happier afterlife than the life they leave behind and expect to meet with their friends, not their enemies. Understandable, authentic, and to a certain extent touching as this is, this kind of thinking is also paradoxical since it may also come dangerously close to a mild form of jihadism. The beckoning perspective of heaven should never lead to a depreciation of earthly life. Martin Luther is quoted-rightly or apocryphally-saying that: "even if I knew that tomorrow the world would go to pieces, I would still plant my apple tree." In other words: we may rightfully anticipate a life hereafter, but this anticipation is no reason to reduce our efforts to live the present life to the fullest.

A third reason to be cautious in using religious arguments is that they are a terrible match for other arguments. Using religious arguments may have a similar effect on ethical discussions as using the word 'bomb' on an airport: try using it, and you will discover that nothing remains the same. After all, if you tell your audience that God does not allow euthanasia or that God does allow it, what else is there to be said? If the creator of the universe, the power behind the big bang, the creator of 100 billion galaxies, tells us that we should, or should not, allow a specific practice, what other possible reaction is there than to reverently bow our heads and say, 'Thy will be done'? Resort to religious arguments may torpedo an open, rational, and empirically informed discussion on the pros and cons of euthanasia. It may lead to intellectual sloth rather than foster curiosity. Religion may tempt religious people to ignore rational and empirical arguments, and insofar as they do embrace these arguments, it sometimes remains to be seen whether their use is wholehearted and open-minded. Do these empirical arguments not come in handy to serve their preconceived religious narrative?

I do believe that there is a God, and I am open to the possibility that our choices about life and death matter to God. However, I also believe that if there is a 'will of God,' the best way to find it out is by exploring all accessible epistemic sources, be it tradition, experience, nature, reason, logic, intuition, and positive law. Religion does not discard these sources but rather justifies and explores them. To name an example outside the realm of euthanasia: I support the UNFCCC Paris climate agreement. The reason is not that God tells us to, nor because the Bible does; it is because scientific evidence tells us that human behaviour is the leading cause of the present climate crisis.

The experience that some religious arguments have a 'take it or leave it' character and have inscrutable epistemological origins has led some secularised audiences not to take seriously the arguments brought forward by religious people. The allergy to religion can become excessive. Some seem to have come to the point of discarding any argument brought forward by religious people. As soon as they learn that Columbus was a Catholic, these people will tend to question the very existence of America. The vice of intellectual sloth is thus found not only amongst religious people, but also in those who reject religious arguments. On multiple occasions, I have experienced that my arguments were discarded beforehand based on my tenure at a theological university. Some forget that arguments from religious people are not necessarily religious arguments; they may still be understandable, convincing, and conclusive. Religion may form the heuristic context to discern values, but is not necessarily their sole epistemological source nor provides their sole justification. We need a détente between religion and reason, not an escalation of the battle (27). 


\section{Concluding Remarks}

As a medical ethicist and a theologian, I have repeatedly stated that I do not reject euthanasia (28). I could and can imagine the exceptional case of killing a patient when nothing else can ease unbearable suffering. Many are familiar with the classroom example of the truck driver who is stuck in his cabin after crashing into a concrete wall and begs a bystander to kill him before he is devoured by fire-killing the driver, in my opinion, may be the least bad alternative. This position has brought me criticism from religious voices, especially from those who argue that I should categorically reject any intentional and direct killing of an innocent human being. However, with Martin Luther, echoing St. Augustine, my position on euthanasia is pecca fortiter-sin courageously, if you think no other option is left.

I, therefore, supported the Dutch euthanasia law in the first years of this century. This support was motivated by the fact that euthanasia is still part of the Criminal Code and respect for the views of a majority of citizens, combined with the experience that the Dutch system seemed effective in keeping the numbers down and the reasons restricted: euthanasia as the last resort to prevent a terrible death. For reasons listed in the introduction, I became more sceptical. None of these reasons is a religious one, as anyone can see: the numbers tripled, the pathologies expanded, and euthanasia increasingly became a preferred way to die. What can also be seen is that the Netherlands is not alone; there is hardly any jurisdiction in the world where an assisted dying practice has remained unchanged for longer than a couple of years. Canada legalised euthanasia in 2016 for patients whose deaths were expected within the near future. In 2019, this restriction was overruled by the Superior Court in Quebec and proclaimed unconstitutional (29). In 2019, Oregon suspended the mandatory 15-day waiting period for some (30).

The list is long in the Netherlands. Euthanasia is now debated for any citizen of 75 years and older, even those whose suffering consists not of an illness but of meaninglessness, cultural and economic detachment, old age, and loneliness (31).In April 2020, the Supreme Court of the Netherlands ruled that euthanasia is possible for incompetent patients in an advanced stage of dementia, even if they resist at the very moment, and they may be put to sleep unwittingly by putting a sedative in the coffee or apple sauce. All this on the condition that they have an advance directive (32). In October 2020, the Dutch government decided that even the lives of children aged 1-11 years may be terminated (33). Finally and tragically, although many euthanasia advocates argue that it reduces the number of violent suicides, the suicide rate has increased rather than decreased (34).

As a religious person, I should be open to discern any element of truth, however inconvenient. In my perception, all these developments testify against an aspect that needs to be faced: that legalising assisted dying is seldom the end of a trajectory of deliberations. Instead, it is the onset of new discussions and further expansion of the practice. Legal euthanasia does more than just giving some people the liberty to opt for another way to die; it revolutionises the fabric of society. Not only life but also death increasingly becomes a project. The liberty of some to choose assisted dying obliges everyone else to face that same option at the end of the day. After all, when a society legalises and facilitates killing thousands of its citizens annually, this is not a signal to those patients only. It is a signal to a whole group of patients - and, in the Netherlands, an ever-expanding group of patients and their relatives-that they may in fact be right if they no longer want to live.

Through legalising assisted dying, the liberal society thus bites its tail. I think that there is an inalienable moral right to kill oneself, provided one is competent and knows what one is doing. However, it is unwise to support this right in the form of assistance in dying. In the long run, no society, religious or not, can afford to organise the killing of groups of its own citizens. The best way to guarantee the exceptional character of mercy killing is by keeping it where it is most safely kept: in the Criminal Code. 


\section{References}

1. Yuill K. Assisted Suicide: The Liberal, Humanist Case Against Legalization. Basingstoke: Palgrave Macmillan; 2013.

2. Chabot B. Verontrustende cultuuromslag rond de zelfgekozen dood. NRC Handelsblad; 2017 Jun 16. Available from: https://www.nrc.nl/nieuws/2017/06/16/ de-euthanasiegeest-is-uit-de-fles-11123806-a1563406.

3. Vandenberg JH. Medische macht en medische ethiek. Nijkerk: Callenbach; 1969.

4. Weyers HAM. Euthanasie. Het proces van rechtsverandering. Groningen: Rijksuniversiteit Groningen; 2002.

5. Oostveen M. Het grote experiment. NRC Handelsblad; 2003 May 24.

6. Boer TA. Euthanasia and Culture: Observations from a Pioneering Country. In: Puyol Montero JM, editor. New Challenges for Law: Studies on the Dignity of Human Life. Madrid/Harvard: Tirant lo Blanch; 2020:179-99.

7. Groenewoud AS, Atsma F, Arvin M, Westert G, Boer TA. Geographical Variation in Euthanasia in the Netherlands: A claims-data based cross sectional study (2013-2017). BMJ Support \& Palliative Care; 2020.

8. Lynch T, Connor SD. Mapping Levels of Palliative Care Development: A Global Update. J Pain Symptom Manage. 2013 Jun;45(6):1094-1107. DOI: 10.1016/j. jpainsymman.2012.05.011

9. Protestant Church in the Netherlands. Euthanasie: zin en begrenzing van het medisch handelen. The Hague: Boekencentrum; 1972.

10. Protestant Church in the Netherlands. Euthanasie en pastoraat. The Hague: Boekencentrum; 1988.

11. Protestant Church in the Netherlands. Verklaring Samen op Weg-kerken. In: Delange F, Jans J, editors. De dood in het geding: euthanasiewetgeving en de kerken. Kampen: Kok; 2000:17-22.

12. Buskes JJ. Waarheid en leugen aan het ziekbed. Baarn: Ten Have; 1964.

13. Buskes JJ. Medische macht. Review of Vandenberg's, Medische macht en medische ethiek. In: Hervormd Nederland; [year unknown].

14. Roscam Abbing PJ. Toegenomen verantwoordelijkheid. Veranderende ethiek rond euthanasie, eugenetiek en moderne biologie. Nijkerk: Callenbach; 1972.

15. Lindeboom GA. Euthanasie en Euthanasiasme. Amsterdam: Buijten \& Schipperheijn; 1979.

16. Dupuis HM. Wat is goed voor een mens. Macht en onmacht van moraal. Amsterdam: Balans; 1987.
17. Kuitert HM. Een gewenste dood: euthanasie als moreel en godsdienstig probleem. Baarn: Ten Have; 1981.

18. Kuitert HM. Suïcide, wat is er tegen? Baarn: Ten Have; 1983.

19. Kuitert HM. Mag er een einde komen aan het bittere einde? Baarn: Ten Have; 1994.

20. The AM. Verlossers naast God: dokters en euthanasie in Nederland. Amsterdam: Thoeris; 2009.

21. Kennedy J. Een weloverwogen dood: Euthanasie in Nederland. Amsterdam: Bert Bakker; 2002.

22. Boer TA, Groenewoud AS. Dutch Reformed support for Assisted Dying in the Netherlands 1969-2019: An analysis of the views of parishioners, pastors, opinion makers, and official reports of the Protestant Church in the Netherlands [Forthcoming]. J Soc Christ Ethics (JSCE);2021 spring/summer;41(1).

23. Maguire D. Death by Choice. Garden City, NY: Doubleday; 1984.

24. Boer, TA, Roothaan A, editors. Gegeven. Ethische essays over het leven als gave. Zoetermeer: Boekencentrum; 2003.

25. Battin MP. Prohibition and Invitation: The Paradox of Religious Views about Suicide. In: The Least Worst Death: Essays in Bioethics on the End of Life. New York and Oxford: Oxford University Press; 1994.

26. Horwitz M. L'euthanasie en débat. In: Actualité Religieuse dans le monde, 1994 Feb 15: 119.

27. McCarthy M, Homan M, Rozier M. There's No Harm in Talking: Re-establishing the Relationship Between Theological and Secular Bioethics. Am J Bioeth. 2020 Dec;20(12):5-13. DoI: 10.1080/15265161.2020.1832611.

28. Boer TA. Rushing towards Death? Assisted Dying in the Netherlands. Christ Cent. 2016 Apr 13;3(4):24-7.

29. Rukavina S. Quebec judge overturns parts of federal, provincial laws on medically assisted dying. свс News; 2019 Sep 11. Available from: https://www.cbc.ca/news/ canada/montreal/medically-assisted-dying-law-overturned-quebec-1.5279067

30. The Oregonean. New law shortens 'Death with Dignity' waiting period for some patients; 2019 Jul 24. Available from: https://www.oregonlive.com/politics/2019/07/new-law-shortens-death-with-dignitywaiting-period-for-some-patients.html.

31. Boztas S. Dutch MP backs euthanasia for over-75s who are 'tired of life.' The Times; 2020 Jul 19. Available from: https://www.thetimes.co.uk/article/dutch-mpbacks-euthanasia-for-over-75s-who-are-tired-of-lifez8bdp6685. 
32. The Guardian. Dutch court approves euthanasia in cases of advanced dementia; 2020 Apr 21. Available from: https://www.theguardian.com/world/2020/ apr/21/dutch-court-approves-euthanasia-in-cases-of-advanced-dementia.

33. BвC. Netherlands backs euthanasia for terminally ill children under-12; 2020 Oct 14. Available from: https://www.bbc.com/news/world-europe-54538288.

34. Boer TA. Legalising assisted dying can actually increase suicides. The Conservative Woman; 2020 Sep 13. Available from: https://www.conservativewoman.co.uk/legalising-assisted-dying-can-actually-increase-suicides/ 